\title{
Potentialities of Water Resources Pollution of the Nile River Delta, Egypt
}

\author{
Hossam Hamdy Elewa*
}

\author{
Department of Water Resources, National Authority for Remote Sensing \& Space Sciences (NARSS), 23 Josef Brows \\ Tito Street, Nozha Gedida, Cairo, Egypt
}

\begin{abstract}
The population growth, economic development with the consequent anthropogenic activities at the Nile Delta of Egypt addresses the present-day hydro-environmental status and quality deterioration trends of surface Nile River water. The hydrochemical fingerprints of surface waters revealed the effects of points and non-points sources of pollution. The relative low $\mathrm{Cl}^{-}$and $\mathrm{SO}_{4}{ }^{2-}$ in Nile water of Damietta and Rosetta branches precludes subjacent sources of polluted water. Mixing of surface Nile waters with other drainage polluted ones was revealed by Ludwig-Langelier and Piper diagrams, where there is a general tendency towards no-dominant water type's regime in the Nile River branches with a certain modification in the hydrochemical facies of the drains waters. This modification is due to their pollution by point and non-point sources. The general tendency of water quality deterioration is generally towards the north. The pattern given by the multivariate statistical clustering technique for water quality discrimination indicated that the chief pollution sources prevalent had some commonality, which reveals similar phenomena of mixing and deterioration pattern, as the water, in general, is coming from one source (Nile River), which was subsequently modified by the natural and anthropogenic activities. The picture with respect to the nature of existing pollutants revealed the tendency of areas associated with parameters like the anthropogenic activities are getting widespread (not concentrated) over the whole area of study.
\end{abstract}

Key Wards: Nile Delta, Egypt, Water Resources, Groundwater Aquifers, Water Quality, Heavy Metals, Water Contamination.

\section{INTRODUCTION}

Nile River Delta $\left(24,900 \mathrm{~km}^{2}\right)$, like many similar deltas of the world, holds ecological and economic values and is a major center of population and agriculture (Fig. 1). In the presence of adequate fluvial sediment supply and minimal human influence, deltas generally maintain their integrity and/or continue to extend seaward [1]. By taking into account the water problem, the World Health Organization (WHO) has recently reported that the two biggest components of the global water crisis are the contamination of drinking supplies with human discharge and the massive wastage of water that is inherent in prevailing agricultural practices (Nature, 6929 issue). The geo-environmental status of Nile Delta in the last few decades had been changed adversely, due to natural and anthropogenic effects. These changes were accelerated due to the previously mentioned parameters, in addition to the universal global warming and over population [2]. In Egypt, the Nile delta represents about $60 \%$ of the total arable lands and it is inhabited by about 30 million people.

The main natural and anthropogenic activities that induced changes in Nile Delta were summarized by Stanley and Warne [3]. Since the closure of the Aswan High Dam in 1969 , nearly most of the sediments carried by the river are entrapped behind the dam. This sediment trapping has resulted in a sharp decrease in sediment supply to the delta. Coastal erosion, wetland loss and saltwater intrusion

\footnotetext{
*Address correspondence to this author at the Department of Water Resources, National Authority for Remote Sensing \& Space Sciences (NARSS), 23 Josef Brows Tito Street, Nozha Gedida, Cairo, Egypt; Tel: +202 26225834; Fax: +202 26225800; E-mail: hossh2@yahoo.com
}

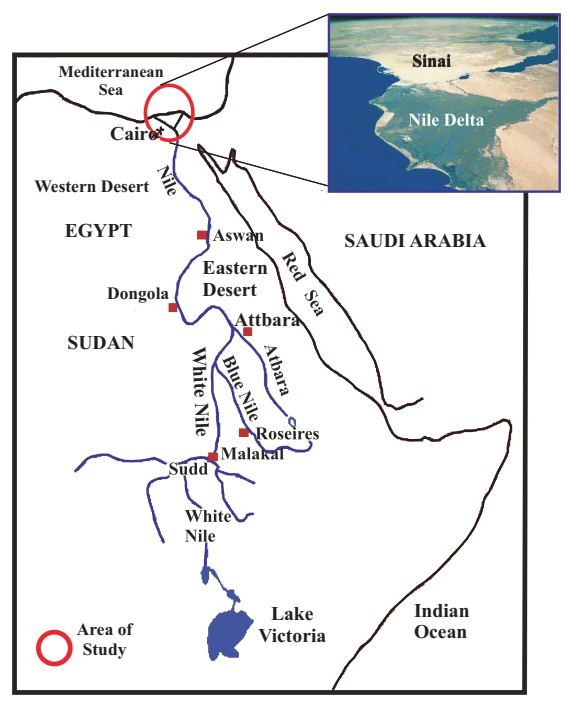

Fig. (1). Location map of the study area.

into Nile delta's aquifers have all been attributed to the decreased sediment input and associated subsidence. Coastal erosion rates close to the Rosetta and Damietta promontories range from 10 to greater than $100 \mathrm{~m} /$ year. In addition to damming, a dense network of irrigation and drainage canals in the delta has trapped much of the remaining sediment, thus preventing it from reaching the coastline.

Depending on a reasonable cluster of recent data and sampling program, the present work aims to throw light upon the present-day hydro-environmental status and quality deterioration trends of surface Nile River water in the Nile Delta area. The trends and magnitude of deterioration could be used as a guide for setting-up an efficient future management 


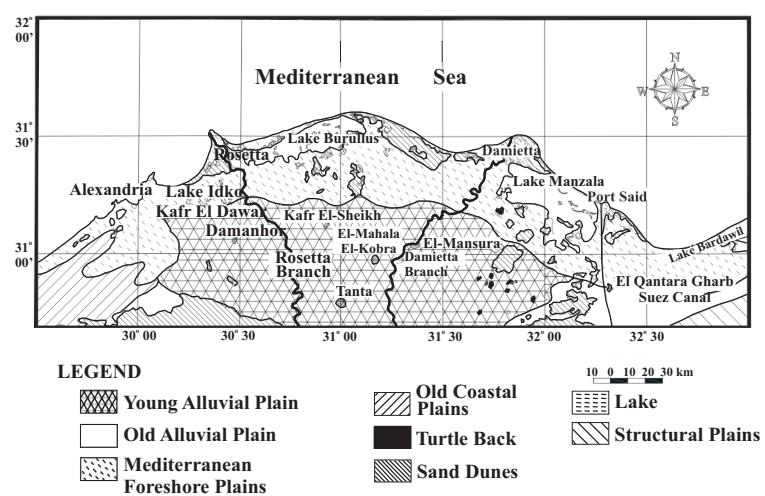

Fig. (2). Geomorphologic map of the northern part of the Nile Delta (Based on landsat ETM+ image, bands 742 (2003)).

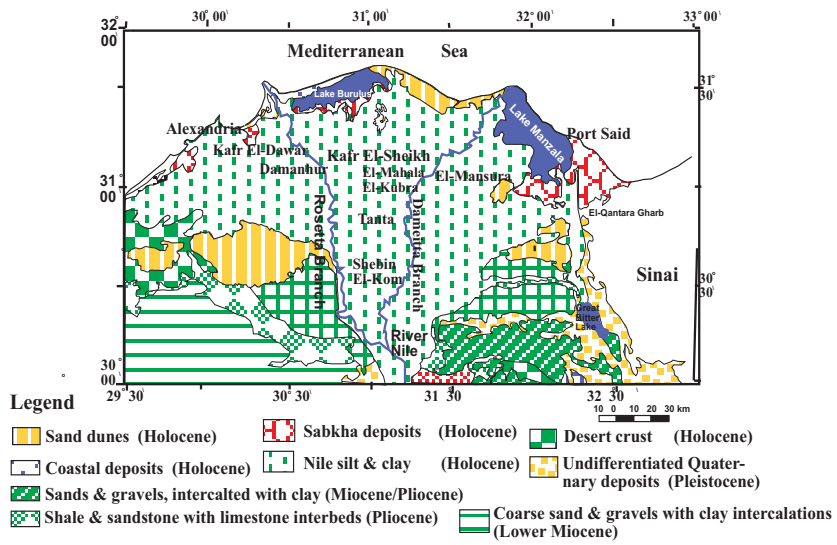

Fig. (3). Geological map of the study area (modified after CONOCO [5] and based on landsat image (2003).

and remediation policy for controlling the land/water use pattern in this vital area of Egypt.

The Nile Delta has a Mediterranean climate, which is characterized by little rainfall. Only 100 to $200 \mathrm{~mm}$ of rain falls on the northern Nile Delta area during an average year, and most of these amounts fall in the winter season. The delta experiences its hottest temperatures in July and August, averaging about $30^{\circ} \mathrm{C}$, with a maximum of about $48^{\circ} \mathrm{C}$. Winter temperatures are normally in the range of $5^{\circ}-10^{\circ} \mathrm{C}$. The Nile Delta region becomes quite humid during the summer months.

\section{GEOMORPHOLOGICAL BACKGROUND}

AND

GEOLOGICAL

The geomorphologic units were delineated on the landsat ETM+ images Mosaic (bands 74 2), taken in 2003, with reference to the units described by the previous workers [4] (Fig. 2). In the mid and northern Nile Delta region, eight geomorphic units could be distinguished. These are young alluvial plain, old alluvial plain, Mediterranean foreshore plain, old coastal plain, turtle backs, sand dunes, lakes, and structural plains.

The Nile Delta area is totally covered by Quaternary deposits consisting of Nile silt, clay, sandy clay, sands and gravels (Fig. 3). Deep oil drilling in the studied area revealed a very thick sedimentary succession. In the southern part of the Delta, a succession of Jurassic-Holocene of about 3214 $m$ thick is encountered. In the middle parts of the Delta, the Quaternary succession is about $500 \mathrm{~m}$ thick. In the northern part of the Delta, the lower Miocene to Holocene sequence attains a thickness of about 3583-4183 m.

Nile Delta comprises precious water resources of great value to humanity. In the last few decades, humans induced vital anthropogenic changes, which have globally outstripped the natural evolutionary processes of the Nile Delta. The changes especially included the contraction of fertile agricultural areas, conversion of non-agricultural areas to agricultural ones (rehabilitation or reclamation), deterioration of agricultural areas, and disruption of the hydrological regimes, which negatively impacted the water quality. This is primarily through water consumption, diversion of the river water for irrigation, discharge of irrigation waste water into the river channels and in situ water use within the river channels.

\section{GROUNDWATER CONDITIONS}

The Quaternary deposits in the Nile Delta form a huge groundwater reservoir (Figs. 3,4). These deposits cover the whole Nile Delta area with a great thickness ranging from about $200 \mathrm{~m}$ in the southern part to $1000 \mathrm{~m}$ in the northern one. The thickness of succession is thinning southwards and on the fringes of the delta. These deposits are water-bearing of free to semi-confined and confined nature according to the lithology of Holocene cap bed, which increases in thickness due north. Generally, the Pleistocene aquifer is free in the south and both fringes, whereas becoming semi-confined and locally confined towards the north (Fig. 4).

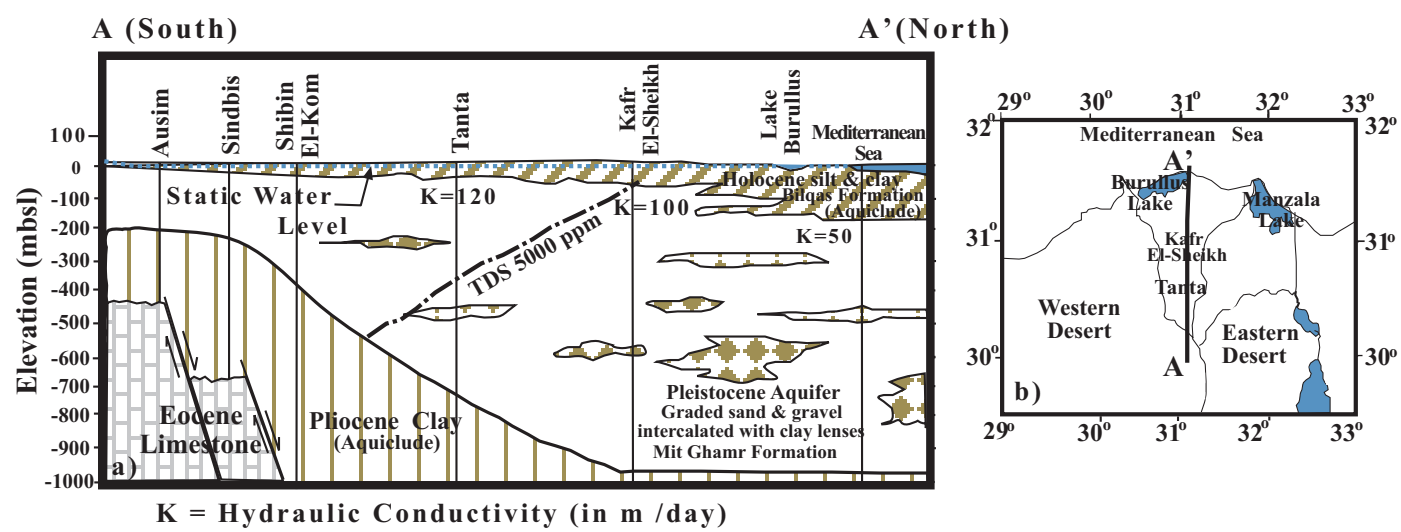

Fig. (4). a) Hydrogeological cross section from south to north of the study area showing the framework groundwater regime in the study area. b) Key map for cross section (A-A'). 
Table 1. Hydrogeological Characteristics on Nile Delta Aquifer

\begin{tabular}{|c|c|c|c|c|}
\hline Location & $\begin{array}{c}\text { Top Aquifer, } \\
(\mathbf{m a s})\end{array}$ & Saturated Thickness (m) & $\begin{array}{c}\text { Depth to Groundwater Level } \\
(\mathbf{m})\end{array}$ & $\begin{array}{c}\text { Transmissivity (m²/day) } \\
(\mathbf{p p m})\end{array}$ \\
\hline \hline $\begin{array}{c}\text { North Nile } \\
\text { Delta } \\
\begin{array}{c}\text { South Nile } \\
\text { Delta }\end{array}\end{array}$ & $0-100$ & $500-1000$ & $0-3$ & $5000-25,000$ \\
\hline
\end{tabular}

Table 2. Factors Affecting the Groundwater Vulnerability in the Nile Delta

\begin{tabular}{|c|c|c|c|c|c|}
\hline $\begin{array}{l}\text { Thickness of Clay } \\
\text { Cap (m) }\end{array}$ & $\begin{array}{l}\text { Vertical Ground- } \\
\text { water Flow }\end{array}$ & $\begin{array}{l}\text { Rate of Recharge } \\
(\mathbf{m m} / \text { day })\end{array}$ & $\begin{array}{c}\text { Depth to Groundwater from } \\
\text { Surface (m) }\end{array}$ & $\begin{array}{l}\text { Groundwater } \\
\text { Vulnerability }\end{array}$ & Location \\
\hline 0 & Downward & --- & $<5$ & High & $\begin{array}{c}\text { Transition zone between old \& } \\
\text { Reclaimed Land }\end{array}$ \\
\hline $0-2$ & Downward & $>1$ & $5-15$ & High & Transition zone \\
\hline 0 & Downward & $<1$ & $>15$ & $\begin{array}{l}\text { Moderate- } \\
\text { High }\end{array}$ & Desert Fringes \\
\hline $0-10$ & Downward & $<1$ & $<5$ & Moderate-Low & $\begin{array}{l}\text { Flood Plain \& Partially Tran- } \\
\text { sition Zone }\end{array}$ \\
\hline$>10$ & Downward & $0.25-1$ & $<5$ & Low & Flood Plain \\
\hline $0->10$ & Upward & $<25$ & $<5$ & Low & North Delta (Flood Plain) \\
\hline
\end{tabular}

The Quaternary aquifer is composed mainly of Nilotic loose quartz sands interbedded with thin clay beds (Mit Ghamr Formation of Pleistocene age). It is generally capped by relatively thin characteristic muddy cap beds (Bilqas Formation of Holocene age). The maximum thickness of Bilqas Formation is $71 \mathrm{~m}$ in the north and $77 \mathrm{~m}$ in the east, decreasing gradually towards the south [6] (Fig. 4 a \& b). At the northern fringes of the Delta, the sediments forming the aquifer are deposited under fluvio-marine environment and are frequently affected by the salt water incursion and the recent salinization trends resulting from the sea level rise in the last few decades [7].

The Holocene deltaic deposits saturating the subsoil water form a leaky aquifer. Groundwater in these deposits exists at shallow depths of about 1 to $1.5 \mathrm{~m}$ below the ground surface. The aquifer is chiefly recharged by the vertical infiltration from irrigation canals and drainage water. The infiltration velocity of irrigation water ranges from $0.01 \mathrm{~m} /$ day in the north to more than $6 \mathrm{~m} /$ day in the south of the Nile Delta [8]. Replenishment from the underlying sands and gravel aquifer through the upward leakage is also possible. The hydraulic parameters of this leaky aquifer vary greatly according to the change in lithology [9]. The transmissivity (T) range is $5000-25,000 \mathrm{~m}^{2} /$ day in northern parts of the delta and $5000-10,000 \mathrm{~m}^{2} /$ day in the southern ones (Table 1), whereas the hydraulic conductivity $(\mathrm{K})$ ranges from 120 $\mathrm{m} /$ day in the southern parts to $50 \mathrm{~m} /$ day in the northern ones (Fig. 4 a \& b). Storage coefficient (S) of the aquifer ranges from $1 \times 10^{-3}$ in the southern parts of the delta to $9 \times 10^{-4}$ in the northern ones [8].

At the southern parts of the Nile Delta, the Pleistocene aquifer is entirely saturated with fresh water. At Tanta, in the middle-Delta, however, only the upper $350 \mathrm{~m}$ of the Pleisto- cene aquifer, which measures about $500 \mathrm{~m}$, is saturated with fresh water. This $350 \mathrm{~m}$ fresh groundwater is resting upon the deteriorated deeper saline water (Fig. 4 a \& b).

The groundwater levels of the Pleistocene aquifer range from $16 \mathrm{mbgl}$ in the southern parts of the delta to less than one meter below ground level in the northern ones [10]. Direction of groundwater flow is from south of the delta towards the north, northwest and northeast.

Lithologically speaking, the cap beds (Bilqas Formation) have sandy facies to the west, becoming clayey to the north and east with some local inclusions of brine water near the northern lakes. This lithological facies change may make control of quality and pollution of groundwater more difficult. At southern Nile Delta, unconfined aquifer is overlain by a permeable layer that allows surface water from the Nile River, surface and/or subsurface drains to percolate down to the water table. Consequently, the groundwater is generally recharged over a wider area and is often shallow with a tendency for interaction with surface water. To the north of the Nile Delta, confined Pleistocene aquifer is less vulnerable to pollution from the direct recharge zone because surface water and contaminants cannot percolate to the water table. If contamination does occur, however, it is often difficult to remedy because confined aquifers are usually deep and the number of points where contaminated water may be pumped out is limited.

The greater vulnerability of unconfined aquifers at the southern parts of the Nile Delta to contamination is a result of the wider area over which they are recharged and through which contamination may occur. However, greater interaction with polluted surface water bodies may lead to contaminants' movement into deeper groundwater horizons to the north [11] (Table 2). The risk of contamination will depend 


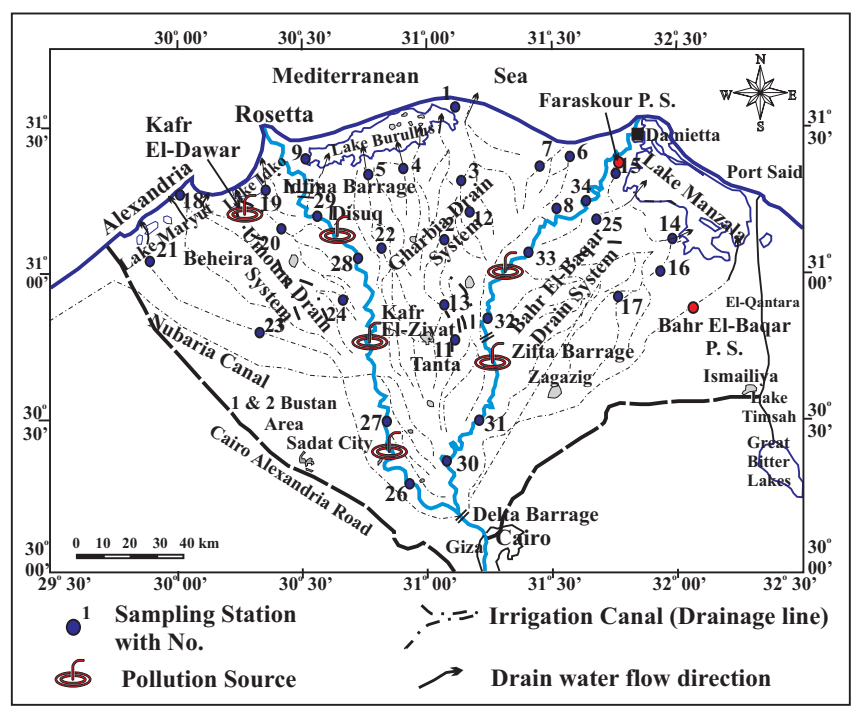

Fig. (5). The Nile River Delta sampling points.

on the thickness of the overlying unsaturated layer, the rate of infiltration to the water table and the land use pattern of the area.

The Nile Delta groundwater vulnerability to pollution is largely determined by the thickness of the clay cap layer, depth to groundwater, rate of recharge, and direction of natural groundwater flow (Table 2). According to these parameters, the Nile Delta region could be distinguished into four categories; I) the reclaimed neighboring desert areas with moderate to highly vulnerable groundwater, due to the presence of sandy formations with high infiltration capabilities and low adsorption capacities, although the groundwater is relatively deep, II) the traditionally cultivated area with moderate to low vulnerable groundwater due to the presence of a clay cap bed, III) the transition zone between the old and reclaimed areas, with highly vulnerable groundwater due to the presence of sandy soil and shallow groundwater level, and IV) the northern part of the delta with very low vulnerable groundwater due to the presence of a thick top clay cap and upward groundwater flow.

\section{SURFACE WATER CONDITIONS}

\section{Fresh Water}

There are two branches of the Nile River; the Rosetta and Damietta (Figs. 3-5). Rosetta is the western branch of about $239 \mathrm{~km}$ long and variable widths of $450-1000 \mathrm{~m}$. It is characterized by variable depths with an average range of 12-20 m (the depth is indicated between banks and bottoms). The branch cuts fine and medium sand of top Holocene sediments in its southern and middle parts, whereas it cuts silty clay with occasional sand lenses in its northern reaches. Therefore, the hydraulic connection between the branch and groundwater is well pronounced in its southern part than that in the northern one [12]. The water level in the Rosetta Branch is controlled by two barrages; Delta Barrage in the south and Idfina Barrage at about $197 \mathrm{~km}$ to the north. On the other hand, the Damietta Branch is about $230 \mathrm{~km}$ long with variable widths of 300 and $500 \mathrm{~m}$. This branch is characterized by variable depths with an average of about $8 \mathrm{~m}$ (Fig. 5).

\section{Drainage Water}

It includes the irrigation canals and the drains. These are widespread over the Nile Delta area. The majority of canals and drains system run towards the Mediterranean coastal plain and discharge their water into the northern lakes or the sea (Fig. 5).

Three main drains systems are established in the Nile Delta; Gharbia main drain at the Middle Delta, El-Ummoum main drain at Western Delta and Bahr El-Baqar main drain at Eastern Delta (Fig. 5). The water table in the open drains is generally maintained at $2.5 \mathrm{~m}$ below ground surface. The open drains system now includes a total of $18,000 \mathrm{~km}$ drains lengths, with bed widths varying from 1 to $30 \mathrm{~m}$ and depths from 2.5 to $6 \mathrm{~m} \mathrm{[13].}$

\section{Saline Water}

The saline water bodies are represented by the Mediterranean Sea, Lakes Burullus, Manzala, Idku and Mariut (Fig. 5).

\section{Methods and Techniques}

In order to study the present-day surface water quality status and pollution potentiality of the Nile Delta, twenty five water samples (samples 1-25) were collected from the irrigation canals and drains of the Nile Delta in 2007. Additionally, nine water samples (samples 26-34) with samples from their bottom sediments were collected from the Nile River Rosetta and Damietta branches (Fig. 5; Tables 3-5) [14]. The 34 water samples were collected from selected locations in Rosetta and Damietta Nile River branches and drains, to express the overall true situation.

The field work included the in situ measurements of oxygen content, $\mathrm{pH}$ and electrical conductivity (EC). All samples analyses were performed according to the Standard Methods for the Examination of Water and Waste Water [15]. To describe the water quality for the study area, the following data were obtained:

- Oxygen Budget: Biological Oxygen Demands (BOD), Chemical Oxygen Demands (COD) and Total Suspended Solids (TSS);

- Salts: Electrical Conductivity (EC), Total Dissolved Solids (TDS), and Sodium Adsorption Ratio (SAR);

- Nutrients: $\mathrm{NO}_{3}-\mathrm{N}$ and $\mathrm{NH}_{4}-\mathrm{N}$.;

- Heavy Metals: Cd, Cu, Fe, Mn, Zn Pb, Ni, Ba and B.

Grab samples of waters and bottom sediments from Rosetta and Damietta Nile branches were collected. Water samples were collected in $250 \mathrm{ml}$ plastic bottles at one-half the total water depth. Sediment samples were cored as $3 \mathrm{~cm}$ in diameter and $5 \mathrm{~cm}$ long. Water samples were preserved with nitric acid and sediment samples were frozen until metal analyses were made. Grain size analysis of the collected sediment samples were performed, which resulted in the definition of textural classes (Table 6).

A detailed study of mixing patterns of surface waters in Nile River branches with the water from irrigation canals and drains was performed. The salinization trends were also elaborated. The pollution potentialities were elaborated through the investigation of pollution sources (point and 
Table 3. Hydrochemistry at Different Sites of Irrigation Canals, Drains and Main Damietta and Rosetta Branches of Nile River

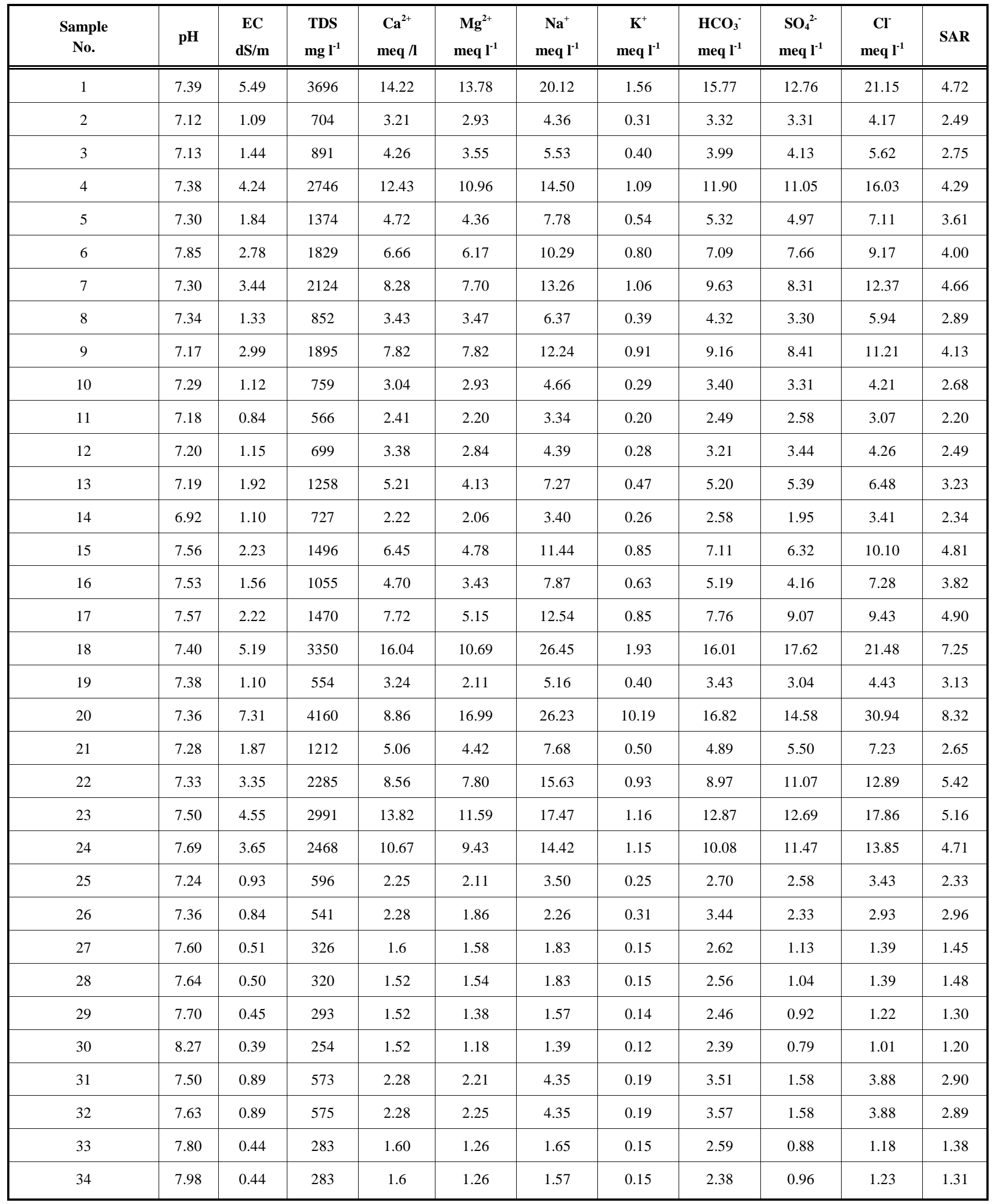

non-points). Plotting the hydrochemical data on LudwigLanglier and Piper diagrams highlighted the trends of possi- ble deterioration, which fingerprinted the potential effect of natural and anthropogenic sources of pollution. 
Table 4. Heavy Metals and Pollution Assessment Parameters at Different Sites of Irrigation Canals, Drains and Main Nile River Damietta and Rosetta Branches

\begin{tabular}{|c|c|c|c|c|c|c|c|c|c|c|c|c|c|}
\hline $\begin{array}{c}\text { Sample } \\
\text { No. }\end{array}$ & $\begin{array}{l}\text { BOD } \\
\mathrm{mg} \mathrm{l}^{-1}\end{array}$ & $\begin{array}{l}\text { COD } \\
\text { mg I }^{-1}\end{array}$ & $\begin{array}{c}\text { TSS } \\
\text { mg I I }^{-1}\end{array}$ & $\begin{array}{c}\mathrm{NO}_{3} \\
\mathrm{mg} \mathrm{I}^{-1}\end{array}$ & $\begin{array}{c}\mathrm{NH}_{4} \\
\mathrm{mg} \mathrm{I}^{-1}\end{array}$ & $\begin{array}{c}\text { Cd } \\
\mathrm{mg} \mathrm{I}^{-1}\end{array}$ & $\begin{array}{c}\mathrm{Cu} \\
\mathrm{mg} \mathrm{I}^{-1}\end{array}$ & $\begin{array}{c}\mathrm{Fe} \\
\mathrm{mg} \mathrm{l}^{1}\end{array}$ & $\begin{array}{c}\text { Mn } \\
\mathrm{mg} \mathrm{I}^{-1}\end{array}$ & $\begin{array}{c}\mathrm{Zn} \\
\mathrm{mg} \mathrm{l}^{-1}\end{array}$ & $\begin{array}{c}\mathrm{Ni} \\
\mathrm{mg} \mathrm{l}^{-1}\end{array}$ & $\begin{array}{c}\mathrm{Pb} \\
\mathrm{mg} \mathrm{I}^{-1}\end{array}$ & $\begin{array}{c}\text { B } \\
\mathrm{mg} \mathrm{l}^{-1}\end{array}$ \\
\hline 1 & 34 & 56 & 81 & 1.320 & 1.930 & 0.003 & 0.082 & 0.747 & 0.307 & 0.476 & 0.041 & 0.013 & 0.397 \\
\hline 2 & 54 & 89 & 60 & 1.508 & 2.023 & 0.008 & 0.115 & 0.785 & 0.097 & 0.036 & 0.035 & 0.014 & 0.428 \\
\hline 3 & 72 & 111 & 68 & 1.456 & 1.658 & 0.004 & 0.037 & 1.143 & 0.318 & 0.215 & 0.085 & 0.016 & 0.448 \\
\hline 5 & 64 & 91 & 115 & 0.858 & 1.659 & 0.002 & 0.037 & 0.902 & 0.161 & 0.045 & 0.124 & 0.012 & 0.325 \\
\hline 6 & 22 & 33 & 33 & 0.333 & 0.587 & 0.001 & 0.029 & 0.233 & 0.048 & 0.010 & 0.010 & 0.035 & 0.065 \\
\hline 7 & 25 & 45 & 41 & 0.609 & 0.333 & 0.001 & 0.035 & 0.263 & 0.085 & 0.022 & 0.014 & 0.026 & 0.078 \\
\hline 8 & 22 & 35 & 45 & 0.507 & 0.520 & 0.001 & 0.023 & 0.217 & 0.069 & 0.027 & 0.007 & 0.025 & 0.065 \\
\hline 11 & 43 & 73 & 63 & 1.380 & 1.203 & 0.001 & 0.047 & 0.572 & 0.259 & 0.082 & 0.054 & 0.008 & 0.376 \\
\hline 12 & 61 & 85 & 66 & 1.194 & 2.543 & 0.003 & 0.043 & 0.570 & 0.267 & 0.037 & 0.058 & 0.007 & 0.339 \\
\hline 13 & 67 & 95 & 87 & 1.192 & 2.669 & 0.017 & 0.028 & 0.756 & 0.173 & 0.174 & 0.067 & 0.013 & 0.220 \\
\hline 14 & 18 & 27 & 122 & 1.492 & 1.598 & 0.004 & 0.029 & 0.425 & 0.177 & 0.049 & 0.026 & 0.016 & 0.325 \\
\hline 15 & 36 & 59 & 69 & 0.941 & 1.077 & 0.001 & 0.039 & 0.209 & 0.137 & 0.035 & 0.041 & 0.007 & 0.201 \\
\hline 16 & 41 & 69 & 97 & 1.065 & 1.515 & 0.002 & 0.046 & 0.375 & 0.094 & 0.080 & 0.024 & 0.015 & 0.073 \\
\hline 17 & 32 & 47 & 55 & 0.920 & 0.488 & 0.003 & 0.011 & 0.217 & 0.258 & 0.016 & 0.041 & 0.020 & 0.207 \\
\hline 18 & 87 & 143 & 114 & 1.47 & 2.83 & 0.001 & 0.020 & 0.970 & 0.170 & 0.050 & 0.040 & 0.020 & 0.270 \\
\hline 23 & 29 & 46 & 50 & 0.925 & 1.813 & 0.001 & 0.030 & 0.988 & 0.208 & 0.320 & 0.093 & 0.010 & 0.331 \\
\hline 24 & 60 & 90 & 147 & 1.748 & 1.683 & 0.005 & 0.042 & 0.733 & 0.352 & 0.130 & 0.159 & 0.163 & 0.469 \\
\hline 25 & 34 & 54 & 55 & 0.358 & 0.932 & 0.001 & 0.47 & 0.654 & 0.132 & 0.041 & 0.046 & 0.140 & 0.108 \\
\hline 26 & 50 & 62 & 82 & 0.017 & 2.70 & 0.001 & 0.002 & 0.561 & 0.133 & 0.040 & 0.010 & 0.005 & --- \\
\hline 27 & 26 & 48 & 19 & 0.86 & 3.60 & 0.001 & 0.001 & 0.128 & 0.061 & 0.021 & 0.014 & 0.008 & --- \\
\hline 28 & 24 & 12 & 20 & 0.84 & 3.80 & 0.002 & 0.002 & 0.138 & 0.050 & 0.013 & 0.012 & 0.007 & --- \\
\hline 29 & 24 & 10 & 19 & 0.90 & 3.80 & 0.002 & 0.001 & 0.138 & 0.047 & 0.006 & 0.008 & 0.005 & --- \\
\hline 30 & 2.64 & 14 & 10 & 4.90 & 0.01 & 0.001 & 0.002 & 0.116 & 0.027 & 0.030 & 0.005 & 0.007 & --- \\
\hline 31 & 16.00 & 28 & 34 & 5.90 & 3.40 & 0.003 & 0.005 & 0.604 & 0.123 & 0.040 & 0.068 & 0.017 & --- \\
\hline 32 & 12.00 & 27 & 34 & 8.50 & 2.70 & 0.001 & 0.002 & 0.750 & 0.142 & 0.060 & 0.025 & 0.007 & --- \\
\hline 33 & 4.70 & 18 & 15 & 5.00 & 0.20 & 0.001 & 0.002 & 0.330 & 0.036 & 0.005 & 0.010 & 0.005 & --- \\
\hline 34 & 3.10 & 15 & 13 & 5.30 & 0.14 & 0.002 & 0.002 & 0.300 & 0.040 & 0.005 & 0.005 & 0.005 & --- \\
\hline
\end{tabular}

Investigation of statistical relationships of water dissolved constituents and the environmental parameters, such as heavy metals, using multivariate statistics (cluster analysis) provided a powerful tool for analyzing water-chemistry 
Table 5. Heavy Metals Properties of Bottom Sediments Along Damietta and Rosetta Branches

\begin{tabular}{|c|c|c|c|c|c|c|c|c|c|c|}
\hline 27 & 7.58 & 0.78 & 262.5 & 50.40 & 23.10 & 0.80 & 0.20 & 0.85 & 3.20 & 6.40 \\
\hline 28 & 7.60 & 0.59 & 1764.0 & 33.60 & 21.0 & 0.70 & 0.20 & 0.80 & 3.67 & 5.60 \\
\hline 30 & 7.60 & 4.45 & 14040.0 & 492.0 & 123.0 & 4.93 & 0.50 & 26.50 & 18.40 & 44.50 \\
\hline 31 & 7.60 & 5.12 & 23192.0 & 720.0 & 160.0 & 12.25 & 0.80 & 33.40 & 32.95 & 69.30 \\
\hline 32 & 7.56 & 6.96 & 25792.0 & 673.0 & 172.0 & 17.70 & 0.73 & 47.40 & 35.70 & 83.90 \\
\hline 33 & 7.55 & 6.24 & 28808.0 & 1670.0 & 192.0 & 15.65 & 0.80 & 52.40 & 39.90 & 77.00 \\
\hline
\end{tabular}

data. This method was used to test the water quality data and determine if samples can be grouped into distinct populations (hydrochemical groups).

\section{RESULTS AND DISCUSSIONS}

\section{Sources of Pollution and Drainage Water Reuse}

The yearly discharges of irrigation water to the coastal lakes (Burullus, Manzala, Mariut and Idku) and Mediterranean Sea are about 15.21 billion $\mathrm{m}^{3} /$ year $(\mathrm{bcm} / \mathrm{y})$, with an average salinity of $2346 \mathrm{mg} / \mathrm{l}$. This quantity is divided among the three delta's regions as 4.169, 6.363, and 4.682 $\mathrm{bcm} / \mathrm{y}$ for Eastern, Middle, and Western Delta, respectively [13].

If compared with the reused quantities of drainage water, the total quantity of the official drainage water reused is about $5.289 \mathrm{bcm} / \mathrm{y}$. The average salinity of the reused drainage water is about $1100 \mathrm{mg} / \mathrm{l}$ [13]. This polluted water when disposed into these natural water bodies will disrupt their environmental balance.

In Eastern Delta, Bahr El-Baqar main drain system discharges about $2.091 \mathrm{bcm} / \mathrm{y}$ of irrigation water with a maxi-

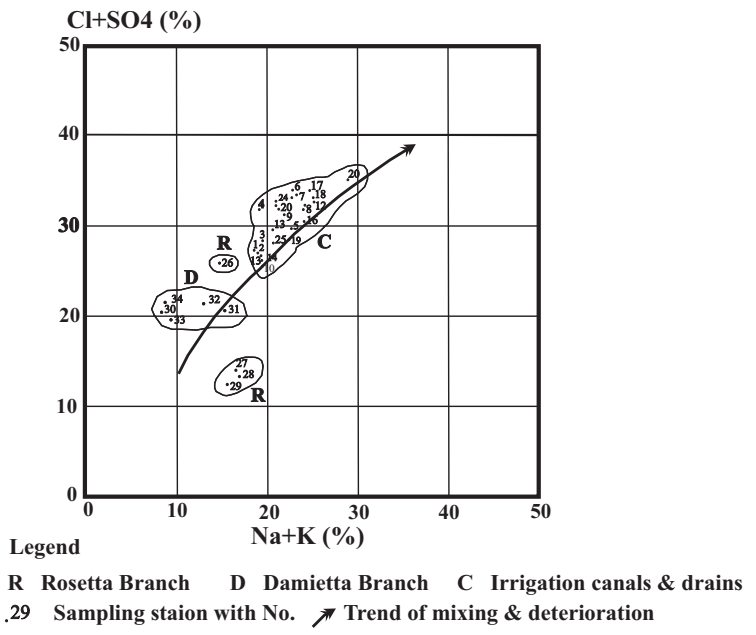

Fig. (6). Langelier-Ludwig diagram [17] revealing the mixing and deterioration trend of surface Nile River and Agricultural drains water. mum salinity and organic matter (BOD) of about 3350 and $87 \mathrm{mg} / \mathrm{l}$, respectively to Lake Manzala (Tables 3-4). This water is polluted by industrial and urban waste water and is considered to be unsuitable for reusing and needs the application of specific treatment before reuse.

From Gharbia main drain system in Middle Delta, 1.017 $\mathrm{bcm} / \mathrm{y}[13]$ is discharged to the sea with a maximum salinity and organic matter (BOD) of about 3696 and $72 \mathrm{mg} / \mathrm{l}$, respectively (Tables 3-4). The total quantity of yearly official reuse is about $1.5 \mathrm{bcm} / \mathrm{y}$.

From El-Ummoum main drain system in Western Delta, $2.533 \mathrm{bcm} / \mathrm{y}$ [13] is pumped to the sea with a maximum salinity and organic matter (BOD) of about 4160 and $60 \mathrm{mg} / \mathrm{l}$, respectively (Tables 3-4). The quantity of reused drainage water depends on the discharge of Ummoum Drain and other sources coming from the newly cultivated lands in Nubaria.

\section{Hydrochemical Fingerprints of Environmental Deterio- ration}

Total dissolved solids (TDS) were measured in $\mathrm{mg} / \mathrm{l}$ and the samples of fresh water collected from Nile branches and those collected from drains were up to or over the maximum admissible concentration of total dissolved solids as stipulated by the WHO [16]. The guideline of water conductivity is $400 \mathrm{dS} / \mathrm{cm}$. From our data, out of the 34 samples, 3 exceeded this guideline (Table $\mathbf{3}$ ).

The relative low content of chloride $\left(\mathrm{Cl}^{-}\right)$and sulfate $\left(\mathrm{SO}_{4}{ }^{2-}\right)$ in samples collected from the Nile River Rosetta and Damietta branches precludes subjacent sources of poor water quality that might be produced due to proximity to the biologic influences, polluted point sources (industrial and sewage) or non-point ones (agricultural waste water). As the Ludwig-Langelier diagram (Fig. 6) elucidates that the drains waters have higher combined relative sodium and potassium content compared to Nile River waters (Table 3 ). The fact that the chloride and sulfate levels are elevated suggests that the sodium and potassium are derived from mixing with other polluted sources of water. The same trend is reflected by Piper trilinear diagram (Fig. 7). It can easily be shown that the analysis of any mixture of waters will be plotted in a straight line [18] (Figs. 6-7). 


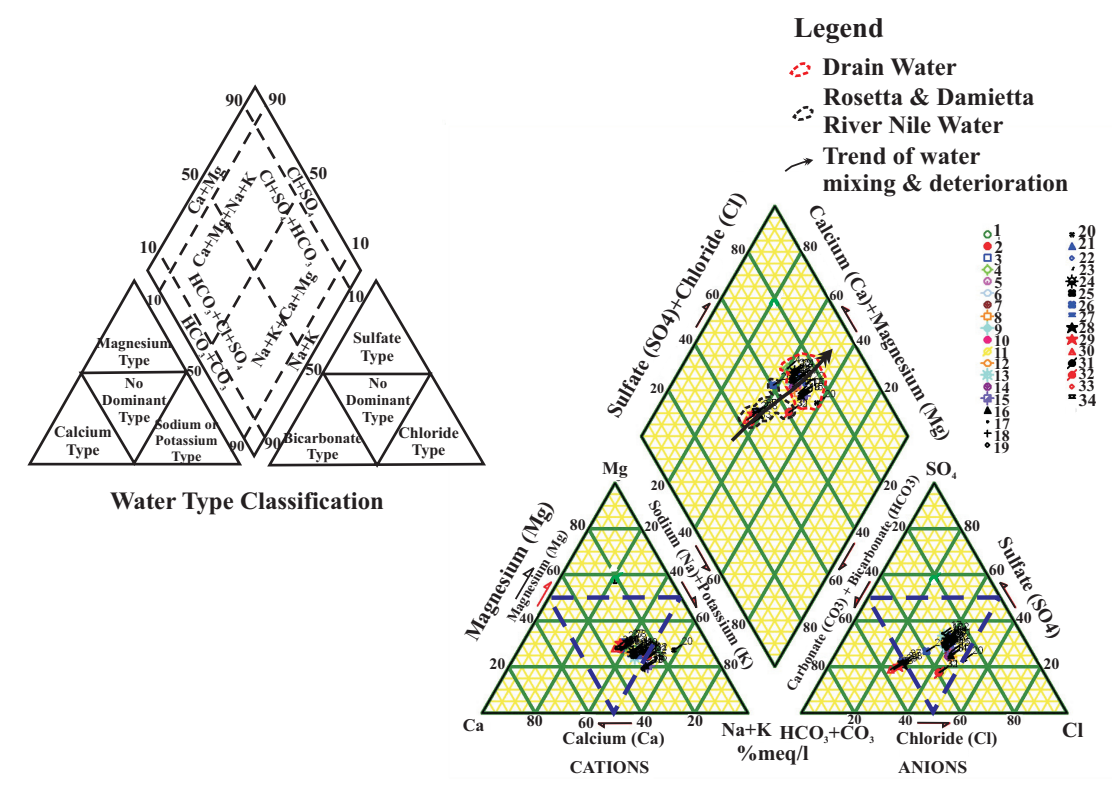

Fig. (7). Piper trilinear plot for hydrochemical facies evolution and classification.

\section{The Hydrochemical Facies Evolution of the Surface Nile River Branches and Drains}

The Piper trilinear diagram ([19]; Fig. 7) is the most widely used graphical method for the delineation of hydrochemical evolution and identification of the dominant processes that control water chemistry. It is quite similar to the diagram proposed by Hill [20 and 21]. This diagram was subsequently modified by Back [22] and Back and Hanshaw [23] to segregate the water-type categories (hydrochemical facies) that form the basis for one common classification scheme for natural waters. Additionally, mixing of water from different sources or evolution pathways can also be illustrated by this diagram [24].

Fig. (7) shows the hydrochemical facies segregation represented by "water types" of surface Rosetta and Damietta Nile waters (samples 26-34) and the agricultural drains (Samples 1-25) (Table 3). The samples of Rosetta and Damietta branches are classified into a variety of water types including $\mathrm{Ca}-\mathrm{Na}-\mathrm{Mg}-\mathrm{HCO}_{3}-\mathrm{Cl}-\mathrm{SO}_{4}$ (or Na-Ca- $\mathrm{Mg}-\mathrm{HCO}_{3}-\mathrm{Cl}-$ $\mathrm{SO}_{4}$ ), Na-Ca- $\mathrm{HCO}_{3}-\mathrm{Cl}-\mathrm{SO}_{4}, \mathrm{Na}-\mathrm{Ca}-\mathrm{Mg}-\mathrm{HCO}_{3}-\mathrm{Cl}$ (or Ca-Na$\mathrm{Mg}-\mathrm{HCO}_{3}-\mathrm{Cl}$ ) and $\mathrm{Na}-\mathrm{Ca}-\mathrm{Mg}-\mathrm{Cl}-\mathrm{HCO}_{3}$. These water types reflect the predominance of bicarbonate alkaline earth waters with higher alkali contents, but with a general tendency towards no-dominant water types' regime. The $\mathrm{pH}$ range is 7.36-7.98, reflecting the slightly alkaline water. The total salinity varies from 254 to $575 \mathrm{mg} / \mathrm{l}$, with a general trend of increase towards north.

On the other hand, the major water types of drains near the northern part of the Nile Delta is $\mathrm{Na}-\mathrm{Ca}-\mathrm{Mg}-\mathrm{Cl}-\mathrm{HCO}_{3}$ $\mathrm{SO}_{4}$ (or Na-Mg-Ca-Cl- $\mathrm{HCO}_{3}-\mathrm{SO}_{4}$ ), $\mathrm{Na}-\mathrm{Ca}-\mathrm{Cl}-\mathrm{HCO}_{3}-\mathrm{SO}_{4}$ (or $\mathrm{Na}-\mathrm{Mg}-\mathrm{Cl}-\mathrm{HCO}_{3}-\mathrm{SO}_{4}$ ) (samples 1, 2, 4, 5, 7, 8, 9, 10, 14, 15, $16,19,20,23$ and 25), where the samples were taken from the drains occurring nearby the saline disposing water bodies represented by the Mediterranean Sea, Lakes Burullus, Manzala and Idku. The drains near their outlets become enriched with the components of agrochemicals and other pollutants, which modify their hydrochemical facies. These samples are characterized by a relative high TDS content, which varies from 596 to $4160 \mathrm{mg} / 1$, with a general trend of increase to- wards north. The relative higher water salinity $(4160 \mathrm{mg} / \mathrm{l}$; Sample 20) reflects the heavy dissolved load of El-Ummoum drain system and Kafr El-Dawar industrial effluents. The $\mathrm{pH}$ value is 6.92-7.56, which characterize water of slightly acidic to slightly alkaline nature. The other southern drains waters are characterized by a relative lower salinity with a general hydrochemical facies of $\mathrm{Na}-\mathrm{Ca}-\mathrm{Mg}-\mathrm{Cl}-\mathrm{SO}_{4}-\mathrm{HCO}_{3}$ (or Na-Ca-Cl-SO $\mathrm{S}_{4}-\mathrm{HCO}_{3}$ ) (samples 3, 6, 11, 12, 13, 17, 18, 21,22 and 24). The $\mathrm{pH}$ range is 7.13-7.85, which refers to slightly alkaline water with a total salinity range of 566-3350 $\mathrm{mg} / \mathrm{l}$. However, higher salinity samples (having same water type) were taken at the outlet of El-Ummoum drainage system near Lake Mariut and at the contact of the Mediterranean Sea (Alexandria Cosmopolitan area). In conclusion, the drains water types had resulted from mixing of different types under different complex physico-chemical processes.

\section{Multivariate Statistical Techniques as a Tool for Hydro- chemical Facies Discrimination}

Another approach to understanding the chemistry of water samples is to investigate the statistical relationships among their dissolved constituents and environmental parameters, such as heavy metals, using multivariate statistics [25]. Statistical associations do not necessarily establish cause-and-effect relationships, but do present the information in a compact format as a first step in the complete analysis of data and can assist in generating hypotheses for the interpretation of hydrochemical processes [26]. Statistical techniques, such as cluster analysis, can provide a powerful tool for analyzing hydrochemical data. Cluster analysis was successfully used, to classify Nile and drains water samples into similar geochemical facies.

Four distinct clusters were observed irrespective of the location (Fig. 8). Cluster analysis indicated that the chief pollutant sources prevalent in these collecting stations had some commonality. It is relevant to indicate that Group III and Group IV occur at relatively elevated places having higher altitudes compared to other two groups (I and II). Cluster (Group) III includes all the Nile Branches water samples in addition to the similar facies of water drains. The 


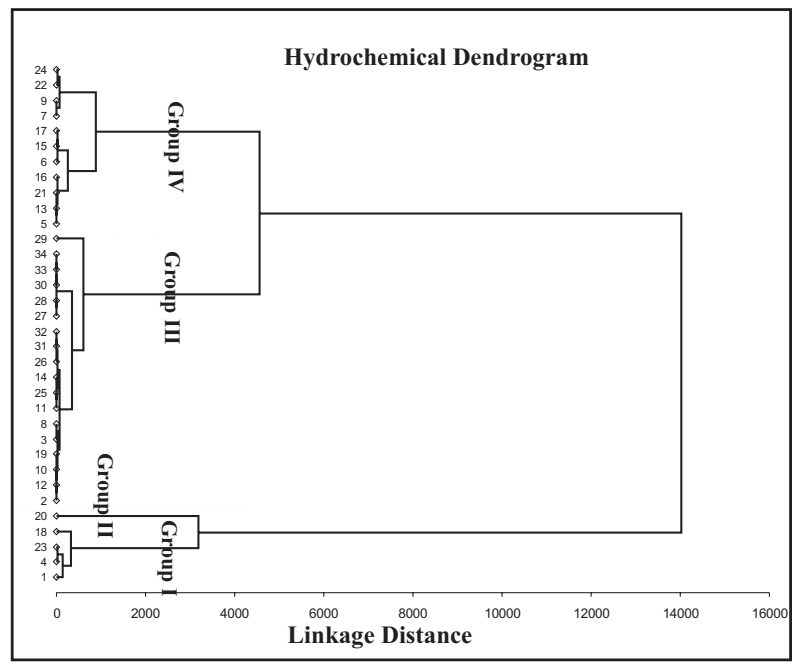

Fig. (8). Dendrogram using Ward's method [27] for classifying the hydrochemical facies of surface Nile River branches and drains.

pattern given by the dendrogram reveals similar phenomena of mixing and deterioration, as the water, in general, is coming from one source (Nile River), which subsequently was modified according to the nature of land use pattern, physiographic features and local sources of pollution. In such case, salinization trend given by the dendrogram is obvious, where the relative salinized samples $(1,4,18$ and 23) where included in one cluster (Group I), located at the northern part of the study area. This cluster represents the most polluted form of these similar hydrochemical facies.

The picture with respect to the nature of the existing pollutants (i. e. heavy metals, BOD, COD, TSS, etc) as brought out by the cluster analysis is characteristic (Fig. 9). Four emerged distinct clusters or groups were elaborated. However, 16 samples were embraced within Group I and II, which belong to the drain water quality. Whereas Groups III and IV comprise the rest of samples belonging to the water of Nile branches and drains. The reason for this was the tendency of areas associated with parameters like "anthropogenic activities" are getting widespread over the whole area of study (especially, the non-point agricultural sources of pollution and other waste waters). However, the pollutants levels, suggest that the concentration was mostly governed by the land-use pattern of the area, where it is relatively intensive in some areas of the drains (groups I and II), which led to the modification of original water quality by the nonpoint sources of pollution (i.e. agrochemicals and others).

\section{Heavy Metals as Environmental Indicators}

Heavy metals are elements having atomic weights between 63.546 and 200.590, and are toxic or poisonous even at low concentrations [28]. Living organisms require trace amounts of some heavy metals, including cobalt, copper, iron, manganese, molybdenum, vanadium, strontium, and zinc. Excessive levels of essential metals, however, could be detrimental to the organism [29]. Naturally occurring metals move through aquatic environments independently of human activities, usually without any detrimental effects. Nonessential heavy metals of particular concern to surface water systems are cadmium, chromium, mercury, lead, arsenic, and antimony [29-31]. All heavy metals exist in surface waters in colloidal, particulate, and dissolved phases. Metals in the

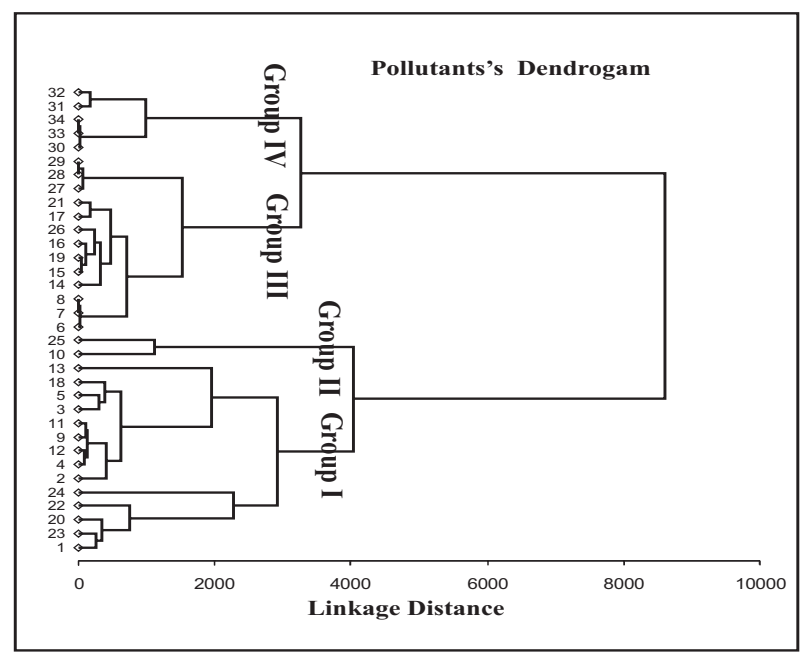

Fig. (9). Dendrogram using Ward's method [27] for classifying the pollutants distribution in mid and northern Nile Delta.

Nile River and Delta come from natural as well as anthropogenic sources.

The sampling of heavy metals from bottom sediments of Rosetta and Damietta Nile branches has been performed in the same locations where water samples were collected, with same numbers (Samples 26-34, Table 5). Bottom sediments of Rosetta and Damietta Nile River branches are composed of a complex mixture of solid phases that may include clays, silica, organic matter, carbonates and large bacterial populations. Table 6 shows the grain size distribution in bottom sediments along Rosetta and Damietta branches. The samples of these sediments were analyzed for heavy metals (Fe, $\mathrm{Mn}, \mathrm{Ba}, \mathrm{Pb}, \mathrm{Cd}, \mathrm{Cu}, \mathrm{Ni}$ and $\mathrm{Zn}$ ). There are three possible mechanisms by which trace metals may be taken up by sediments [32]: 1) physico-chemical adsorption from the water column, 2) biological uptake by organic matter or organisms, and 3) physical accumulation of metal enriched particulate matter by sedimentation or entrainment.

In recent years there has been a significant debate within the scientific community as to the effect of grain size on the adsorption of heavy metals in sediments [33]. Particle dimension is one of the most significant parameters influencing trace metals levels in sediments. Bio-available sedimentbound metals depend, to a great extent, on the particle size fraction with which a metal is associated. Traditionally, the fine particles (silt and clay) fraction of the sediment has been used to examine metals [34]. In the present paper, the performed grain size analysis on the collected bottom sediments samples of Rosetta and Damietta Nile branches revealed a significant variation between both branches. The percentage of fine particles in Damietta Nile Branch (Samples 30-34) is much more than that of Rosetta Branch. Consequently, it is suggested that the concentrations of organic matter and adsorbed heavy metals in the fine-grained fraction of the sediments were often higher than that in the sand-sized fraction. Tam and Wong [34] reported that $\mathrm{Cu}, \mathrm{Zn}, \mathrm{Mn}, \mathrm{Pb}, \mathrm{Ni}, \mathrm{Ba}$, $\mathrm{Cd}$ and $\mathrm{Fe}$ increased in concentration with finer sizedsediments (Tables 5-6; Fig. 5 for locations). Although more metals were retained in the fine-grained sediments in most samples of Damietta Branch, metals would be accumulated in the sand-sized fraction of Rosetta Nile Branch, if the bot- 
Table 6. Grain Size Distribution in Bottom Sediments along Damietta and Rosetta Branches

\begin{tabular}{|c|c|c|c|c|c|}
\hline \multirow{2}{*}{ Sample No. } & \multicolumn{4}{|c|}{ Size Distribution \% } & Textural Class \\
\cline { 2 - 5 } & Gravel & Sand & Silt & Clay & Medium to Coarse Sand \\
\hline \hline 26 & 4.04 & 95.86 & 0.10 & 0.00 & Medium to Coarse Sand \\
\hline 27 & 8.43 & 91.45 & 0.12 & 0.00 & Medium to Fine Sand \\
\hline 28 & 1.00 & 98.32 & 0.68 & 0.00 & Medium Sand \\
\hline 31 & 0.00 & 100.0 & 0.00 & 0.00 & Clayey Medium to Fine Sand \\
\hline 32 & 0.00 & 69.19 & 7.65 & 23.16 & Sandy Silt \\
\hline 33 & 0.00 & 37.37 & 44.46 & 18.17 & Clayey Silt \\
\hline 34 & 0.00 & 4.11 & 60.60 & 35.29 & Clayey Silt \\
\hline
\end{tabular}

tom sediments received heavy metals from prolific anthropogenic inputs.

Previous workers stated that the clay fraction is more important substrate for metal attachment and metal concentrations tended to increase from sand to silt (up to a 2 fold increase), whereas, the increase from silt to clay averages a 4-5 [34] (Tables 5-6). It is infrequent that the predominately coarse-textured soils and sediments become contaminated with problematic levels of trace and toxic metals because such minerals have a low affinity for these elements [33]. So, the primary decisive element behind the enriched metals in Damietta Nile branch bottom sediments compared to that of the Rosetta Branch is the bottom sediments grain size rather than the pollution magnitude or severity.

As can be seen from Table $\mathbf{5}$, metal levels in bottom sediments of Nile River Rosetta and Damietta branches (Samples 26-34) exist in the order $\mathrm{Fe}>\mathrm{Mn}>\mathrm{Ba}>\mathrm{Zn}>\mathrm{Cu}>$ $\mathrm{Ni}>\mathrm{Pb}>\mathrm{Cd}$.

On the other hand, the surface fresh Nile River water (Samples 26-34, Table 4) revealed a sequence of dominance of $\mathrm{Fe}>\mathrm{Mn}>\mathrm{Zn}>\mathrm{Ni}>\mathrm{Pb}>\mathrm{Cd}$. The samples taken from the drains revealed another sequence of $\mathrm{Fe}>\mathrm{B}>\mathrm{Mn}>\mathrm{Zn}>\mathrm{Cu}>$ $\mathrm{Ni}>\mathrm{Pb}>\mathrm{Cd}$, which reflects the fingerprints of agrochemicals and wastewater disposals. All samples of bottom sediments and drain waters attain high levels above those recommended by the US EPA standards [35].

Cadmium concentrations in the bottom sediments range from 0.10 to $0.80 \mathrm{mg} / \mathrm{kg}$, which are low and beneath the contamination levels in sediments $(80 \mathrm{mg} / \mathrm{kg})$ [35]. The same conclusion could be attained with the surface water samples of Rosetta and Damietta Nile branches. Cd is potentially toxic element and has a long biological life of 20-30 years in the kidney [36]. Chronic exposure may eventually accumulate to toxic levels, one of whose consequence may be Itaiitai Byo disease, which is characterized by anemia, damaged proximal tubules, severe bone pain and mineral loss [37]. Recommended level for Cd in water by WHO [38] is 0.003 $\mathrm{mg} / \mathrm{l}$. Six samples out of 25 drain water samples were above this level (Samples 2, 3, 9, 13, 14, and 24), whereas all samples taken from the fresh waters of the Nile branches were within the permissible levels (Table 4). However, higher levels of cadmium may be found in water near industrial effluents or hazardous waste sites (i.e. near Talkha fertilizers manufacturing area in Mansura in East Nile Delta and others).

Higher levels of copper concentrations are established within the bottom sediments of Damietta Branch reaching 26.50-61.20 mg/kg compared with the relative low levels at Rosetta Branch $(0.42-0.75 \mathrm{mg} / \mathrm{kg}$ ) (Table 5). Copper levels in fresh water samples of Rosetta and Damietta branches (0.001-0.005 mg/l) are within the accepted levels of US EPA standards [35], but increase in the drains waters to 0.01-0.47 $\mathrm{mg} / \mathrm{l}$, which occur under the effects of different pollutants. In all instances, these levels are of little environmental effects (Table 4).

Zinc is a ubiquitous essential trace metals and is considered to be relatively non-toxic [31]. All the samples contained $\mathrm{Zn}$ in reasonable concentrations. Happily, zinc does not accumulate with continued exposure; rather, body content is modulated by homeostatic mechanisms that act mainly on absorption and liver levels [39]. From the results of recent researches, the zinc level prescribed by the WHO [38] is $3 \mathrm{mg} / \mathrm{l}$. The US EPA [35] states that zinc concentration in sediments must be above $360 \mathrm{mg} / \mathrm{kg}$ to be considered as a contaminant. Levels in bottom sediments are found to be 4.95-83.90 mg/kg (Table 5), 0.005-0.06 mg/kg along the Rosetta and Damietta Nile water and 0.010-0.476 mg/kg in the drain waters (Table 4). All concentrations can be considered to be within the permissible levels and present little or no environmental hazards.

Manganese is an essential element and co-factor for several enzymatic reactions. Higher levels of manganese reaching 492-1970 mg/kg are established at Damietta Nile Branch bottom sediments (Samples 30-34), which are high compared to those of the Rosetta Branch $(28.35-50.40 \mathrm{mg} / \mathrm{kg}$; Samples 26-29) (Table 5). It would appear that these levels pose a somewhat risk to the surrounding environment and should be closely monitored to prevent any further increase. The concentrations would suggest more discharge rates than the other sampling sites. WHO [16] action level for Mn in water is $0.1 \mathrm{mg} / \mathrm{l}$. The surface fresh water samples attain low 
levels of Mn concentrations of $0.027-0.142 \mathrm{mg} / \mathrm{l}$, where only two samples out of 20 samples were above the standard level. Compared with the drain water samples, twenty samples out of 25 samples were above the recommended level, where levels in drains waters are 0.048-0.383 mg/l (Table 4). Consequently, these results declare major threat from $\mathrm{Mn}$ poisoning effect except for two samples in the surface Nile water and five samples in the drain waters. Toxicity from $\mathrm{Mn}$ manifests the profound increase in the incidence of respiratory diseases. In chronic cases, there may be a neuropsychiatric disorder characterized by irritability, difficulty in walking, speech disturbance, compulsive behavior that may involve running, fighting and singing. If there is chronic Mn toxicity, it results in Parkinson-like syndrome [40].

Lead is the most ubiquitous toxicant in the environment [41]. Therefore, body levels depend on the environmental conditions of exposure. Lead may impair renal function, red blood cell production, the nervous system and causes blindness. According to the US EPA Standards [35], lead $(\mathrm{Pb})$ levels in sediments over $110 \mathrm{mg} / \mathrm{kg}$ are deemed to be high and can begin to have a small but detrimental effect on the surrounding environment. Since the levels from bottom sediments of Rosetta and Damietta Nile branches are below the standards $(0.50-17.70 \mathrm{mg} / \mathrm{kg}$; Table 5), they are not extreme $(0.005-0.017 \mathrm{mg} / \mathrm{l})$ in water samples of Nile River branches with an overall range $(0.006-0.163 \mathrm{mg} / \mathrm{l})$ in drains waters, where only two samples ( 24 and 25 ; Table 4) were above the recommended level $(0.10 \mathrm{mg} / \mathrm{l})$ prescribed by the WHO [38]. Although the problem does not appear to be extensive but is still substantial and needs to be monitored to prevent any permanent rising in level. Industrial effluents to the Nile must be treated to sustain reasonable $\mathrm{Pb}$ levels.

\section{Transition Metals: Iron and Manganese}

Dissolved iron $\left(\mathrm{Fe}^{2+}\right)$ and manganese $\left(\mathrm{Mn}^{2+}\right)$ are nuisance contaminants common in groundwater sources that are anoxic or anaerobic (devoid of dissolved oxygen). Neither metal is toxic to human health in any concentration. Indeed, both iron and manganese are micronutrients required for most forms of life. Nevertheless, even small concentrations of either $\mathrm{Fe}$ or $\mathrm{Mn}$ have unpleasant effects in drinking water supplies. Both iron and manganese can be tasted at concentrations of less than $0.5 \mathrm{mg} / \mathrm{l}$. At this and higher concentrations in most samples taken from the running Nile River and drains water are higher than the recommended levels. The U.S. EPA [35] has established maximum contamination levels of $0.2 \mathrm{mg} / \mathrm{l}$ for iron and $0.05 \mathrm{mg} / \mathrm{l}$ for manganese to safeguard against nuisance effects of water taste. The higher levels of these two elements may be a function of water stagnation under low flow conditions and thus the water is not sufficiently oxygenated. Though, increasing the Nile water discharge may make the concentration of these metals to drop down beneath the detection levels. Iron is an essential metal but due to the frequent acute and chronic Fe over load, which may result in renal failure and hepatic cirrhosis, it is worthy to note its adverse effects which is usually common [42]. Considering the WHO standard [38] of $0.01 \mathrm{ppm}$, some of the samples was excessively overloaded (Tables 4-5). Samples of drains waters carry levels of $0.209-1.143 \mathrm{mg} / \mathrm{l}$, which are far from the recommended ones. Rosetta and Damietta Nile waters are of lower ranges, but still higher than the recommended ones (Table 4). The results from the bottom sediments were well outside the recommended levels for $\mathrm{Fe}$ in sediments [35], where levels of $(262.5-29085.0 \mathrm{mg} / \mathrm{kg}$, Table 5) were elaborated. These extremely high levels are as a result of all anthropogenic activities that take place around the Nile River.

\section{Nutrients: Nitrate and Ammonia}

Nitrate $\left(\mathrm{N}-\mathrm{NO}_{3}{ }^{-}\right)$is an important indicator of domestic, agricultural, industrial, and urban pollution [43]. Very few earth materials are made of nitrate minerals, and as a result, the presence of this anion in water usually indicates pollution from either non-point (agrochemicals and urban runoff) or point sources (wastewater treatment effluents). Although natural life processes do introduce nitrate to the environment (through bacterial nitrogen fixation, or the decay of proteinaceous organic material), their inputs are balanced in healthy aquatic environments by the natural demand of the ecosystem and the uptake of nutrients by algae and plants. Nitrates promote algal and other vegetable growths in the main stream and branches of the Nile River (Nile Roses), which resulted eventually in a severe eutrophication. Generally, relative higher concentrations of nitrates are detected in drains waters than in Nile water, which is due to the excessive use of agrochemicals and dead organic remains (Table 4). The US EPA [35] regulates domestic American water supplies with a maximum contamination level for nitrate in drinking water of $10 \mathrm{mg} / \mathrm{l}$.

Increases of $\mathrm{N}_{-} \mathrm{NO}_{3}{ }^{-}$and decreases in $\mathrm{N}-\mathrm{NH}_{4}{ }^{+}$have been identified in several Nile River locations (Samples 26-34) (Table 4), with a general trend of increase towards north (Nile downstream). Particularly, these trends likely reflect the improved aeration of wastewater effluents, whereby ammonia is nitrified to nitrate. It is also possible that reduced loading of oxygen demanding materials allows the river streams to remain aerated, thus decreasing the in-stream production of ammonia. In all instances, the $\mathrm{N}^{-} \mathrm{NH}_{4}{ }^{+}$levels in the study area reflects higher values if correlated with the natural ranges recorded for healthy and unpolluted rivers (0.005-0.04) [44].

BOD, COD and (TSS) are vital tests for the assessment of the quality of effluents and waste waters prior to discharge [43]. The BOD of the Nile River stream is relatively much lower than that recorded for the drains waters. In anaerobic conditions, failures are often due to the incorrect levels of carbon, nitrogen and phosphorous. In this case, the anaerobic microbes required to perform the degrading function will die if not provided with the correct balance of nutrients. As they oxidize they produce acid, which disrupts the total balance of the microbial populations. Due to the competitive nature of microbes, the non-beneficial bacteria will dominate producing an excessive level of pathogens and toxins. This will lead to "stalling" or grid-lock and high BOD's with foul odors as noticed everywhere around any drain canal in the Nile Delta. Higher levels of BOD, COD and TSS are established in the drains waters, where values of 18-87 mg/l for BOD, 27-143 $\mathrm{mg} / \mathrm{l}$ for COD, and 33-122 mg/l for TSS (Table 4) occur.

\section{CONCLUSION AND RECOMMENDATIONS}

The hydrogeological and hydrochemical criteria used in the present work highlighted clear symptoms and trends of water quality deterioration in the Nile River Delta area, 
which were caused by anthropogenic point and non-point sources of pollution. The trend of deterioration increases from the original River Nile Branches to the drains waters. The Nile water types reflect the predominance of bicarbonate alkaline earth waters with higher alkali contents, TDS range of $254-575 \mathrm{mg} / \mathrm{l}$, with a general tendency towards nodominant water types. On the other hand, the drains waters are characterized by a relative higher salinity that may reach to $4160 \mathrm{mg} / \mathrm{l}$ or more, with a general trend of increase towards north. Also, certain modifications in the hydrochemical facies of the drains waters had been resulted, which are due to mixing with other polluted sources. Heavy metals in Nile and drains waters and bottom sediments of the Nile branches indicted that some metals exhibit alerting hazardous levels, which need more attention and further monitoring. Cluster statistical analysis elucidated that the chief pollutant sources in the Nile Delta had some commonality, as parameters like "anthropogenic activities" are getting widespread over the whole area of study. Certain short-term and long-term remediation policies must be undertaken to alleviate the surface water resources pollution in the River Nile Delta. Excessive Nile discharge within the Nile branches and some severely polluted irrigation drains could alleviate the problem of salinity and heavy metals accumulation or concentration. Irrigation waste water must be treated aggressively before reusing, which is already an on-going project in Egypt. Prohibition of the point sources of pollution from disposing their pollutants into any fresh water body within the Nile Delta, together with the application of efficient treatment techniques before disposing them into the saline water bodies, which will lead to a better remediation of the problem.

\section{ACKNOWLEDGEMENTS}

The author is greatly indebted to Prof. Ayman El Desouky, Chairman of National Authority for Remote Sensing \& Space Sciences of Egypt for providing funding and facilities to accomplish a research project entitled "HydroEnvironmental Assessment and Control on Areas Affected by Nile Delta Hydrodynamic System". The author principally investigated the mentioned project, and the present manuscript is a part of that work. The author is also grateful for the editorial board of the Open Hydrology Journal for their fruitful suggestions and revisions, which maximized the quality of the work.

\section{REFERENCES}

[1] Sanchez-Arcilla A, Jimenez JA, Valdemoro HI. The Ebro Delta: morphodynamics and vulnerability. J Coast Res 1998; 14: 754-72.

[2] El Banna MM, Frihy OE. Natural and anthropogenic influences in the northeastern coast of the Nile Delta, Egypt. Environ Geol 2009; 57: 1593-602.

[3] Stanley JD, Warne AG. Nile Delta in its destructive phase. J Coast Res 1998; 14: 794-825.

[4] Zaghloul ZM, Andrawis SF, Ayyad SN. New contribution to the stratigraphy of the tertiary sediments of the Kafr El Dawar Well-1, Northern Nile Delta, Egypt. Ann Geol Surv Egypt 1979; 9: 292307.

[5] CONOCO. Geological map of Egypt, Scale 1:500,000, Nile Delta, NH-36. Egyptian General Petroleum Corporation 1987.

[6] Zaghloul ZM, Izza Gh M, El Shirbini M, El Hkriby EM. Contribution to the origin of the turtle backs in the Nile Delta area, Egypt. Abstract at symposium on quaternary and development in Egypt, Sponsored by the Academy of Scientific Research and Technology in Collaboration with Geology Deptartment Fac of Sci Mansoura University Egypt 1989.
[7] Elewa HH, El Nahry AH. Hydro-environmental status and soil management of the Nile River Delta, Egypt. Environ Geol 2009; 57: 759-74. (published online 2008).

[8] Dahab K. Hydrogeological evaluation of the Nile Delta after High Dam construction. Ph.D. thesis, Menoufia University, Egypt 1993.

[9] Saleh MF. Some hydrological and hydrochemical studies on the Nile Delta M.Sc. thesis, Ain Shams University, Egypt 1980; p .136.

[10] RIGW (Research Institute for Ground Water). Hydrogeological map of Nile Delta, Scale 1:500, 000, $1^{\text {st }}$ ed. Nile Delta Sector 1992.

[11] Khater A, Fadl A, Fekry A. Statistically-based vulnerability mapping approach and assessment of specific groundwater quality problems in the Nile Delta. NAWQAM Workshop, Alexandria, Egypt 2003.

[12] Diab MS, Saleh MF. The hydrogeochemistry of the Pleistocene aquifer, Nile Delta, Egypt. Int Environ Conf Alexandria, Egypt 1981.

[13] DRI (Drainage Research Institute). Drainage water status in the Nile Delta. Year Book. National Water Research Center, Egypt 2004; Technical report No. 70

[14] NARSS (National Authority for Remote Sensing and Space Sciences). Hydro-environmental assessment and control on areas affected by Nile Delta hydrodynamic system. Internal Unpublished Report 2007; p. 350.

[15] Standard methods for the examination of water and wastewater, $19^{\text {th }}$ ed. American water works association, 6666 Quincy Ave., Denver CO. 1995; 80235, 1-800-926-7337.

[16] WHO (World Health Organization). Guidelines for drinking water quality. WHO, Geneva 1984.

[17] Langelier WF, Ludwig HF. Graphical methods for indicating the mineral character of natural waters. J Am Water Works Assoc 1942; 34: p. 335.

[18] Hem JD. Study and interpretation of the chemical characteristics of natural water. Washington, DC U.S. Gov. Print. Office, 1992.

[19] Piper AM. A graphic procedure in the geochemical interpretation of water analysis. Am Geophys Union Trans 1944; 25: 914-33.

[20] Hill RA. Geochemical patterns in Coachella Valley. Trans Am Geophys Union 1940; 21: 46-49.

[21] Hill RA. Salts in irrigation waters. Trans Am Soc Civil Eng 1942; 107: 1478-93.

[22] Back W. Techniques for mapping of hydrochemical facies. US Geol Surv Prof Pap 1961; 424-D: 380-82.

[23] Back W, Hanshaw BB. Chemical geohydrology. Adv Hydrosci 1965; 2: 49-109.

[24] Freeze RA, Cherry JA. Groundwater. Englewood Cliffs: NJ Prentice Hall: 1979.

[25] Drever JI. The geochemistry of natural waters, $3^{\text {rd }}$ ed. Upper Saddle River: NJ Prentice- Hall 1997.

[26] Güler C, Thyne GD, McCray JE, Turner AK. Evaluation of graphical and multivariate statistical methods for classification of water chemistry data. Hydrogeol J 2002; 10: 455-74.

[27] Ward JH. Hierarchical grouping to optimize an objective function. J Am Stat Assoc 1963; 69: 236-44.

[28] Lenntech Water Treatment and Air Purification. Water Treatment, Published by Lenntech, Rotterdamseweg, The Netherlands 2004. Reference Available from: www.excelwater.com/thp/filters/WaterPurification.htm

[29] Young RA. Toxicity Profiles: toxicity summary for cadmium, risk assessment information system, RAIS, University of Tennessee 2005. Reference Available from: www.rais.ornl.gov/tox/profiles/cadmium.htm

[30] European Union. Heavy Metals in Wastes, European Commission on Environment 2002. Reference Available from: http://ec.europa.eu/environment/waste/studies/pdf/heavy_metalsrep .ort.pdf

[31] Nolan K. Copper toxicity syndrome. J Orthomol Psychiatry 2003; 12 (4): 270-82.

[32] Hart B. Uptake of trace metals by sediments and suspended particulates: a review. Hydrobiologia 1982; 91: 299-313.

[33] Mukherjee PK. Nature and causes of arsenic contamination in groundwater from shallow aquifers in parts of Hooghly River Delta with special reference to the influence of geomorphology in creating the pattern. Ph. D. thesis, Kalyani U, India 2007; p. 178.

[34] Tam NFY, Wong YS. Spatial variation of heavy metals in surface sediments of Hong Kong mangrove swamps. Environ Pollut 2000; 110: 195-205. 
[35] US EPA (US Environmental Protection Agency). Great Lakes water quality initiative criteria documents for the protection of human health. March 1995 EPA-820-B-95-006.

[36] WHO (World Health Organization). IPCS environmental health criteria 134 Cadmium. WHO, Geneva 1992.

[37] Hodgson E, Levi PE. A textbook of modern toxicology. London: Elsevier 1987.

[38] WHO (World Health Organization). Guidelines for drinking water. Health criteria and other supporting information. WHO, Geneva 1998.

[39] Walshe CT, Sandstead HH, Prasad AS. Zinc: Health effects and research priorities for the environment. Health Perspect 1990; 102 (Suppl 2): 5-46.
[40] Mena I, Meurin O, Feunzobda S, Cotzias GC. Chronic manganese poisoning. Clinical picture and manganese turnover. Neurology 1967; 17: 128-36

[41] Goyer RA. Lead toxicity: Current concerns. Environ Health Perspect 1993; 100: 177-87.

[42] Muller-Eberhand U, Miescher PA, Jaffe ER. Iron excess. Aberrations of iron and porphyrine metabolism. New York: Grune and Stratton 1977.

[43] Economopoulos A. Assessment of sources of air, water, and land pollution, WHO, Geneva 1993.

[44] Meybeck M. Global chemical weathering of surficial rocks estimated from river dissolved loads. Am J Sci 1987; 287: 401-28.

Received: February 24, 2009

(C) Hossam Hamdy Elewa; Licensee Bentham Open.

This is an open access article licensed under the terms of the Creative Commons Attribution Non-Commercial License (http://creativecommons.org/licenses/by-nc/3.0/) which permits unrestricted, non-commercial use, distribution and reproduction in any medium, provided the work is properly cited. 